\title{
Diseminasi Teknologi Perbenihan Kelapa dalam Melalui Produksi Benih Perkebunan di Mamuju
}

\author{
Ketut Indrayana* dan Muh. Ricky \\ Balai Pengkajian Teknologi Pertanian Sulawesi Barat \\ Jl. Abdul Malik Pattana Endeng Mamuju Sulawesi Barat \\ * Email: ketutindrayanastp@gmail.com
}

\begin{abstract}
Sampai saat ini produktivitas kelapa dalam di Sulawesi Barat masih rendah sekitar, yaitu 0,9 ton/ha lebih rendah dari produktivitas kelapa dalam nasional yaitu 1,1 ton kopra/ha/tahun. Salah satu faktor yang menentukan tingginya produktivitas tanaman, termasuk kelapa adalah kualitas benih yang ditanam. Pemilihan benih kelapa dalam yang baik dan benar mutlak diperlukan untuk memperoleh benih unggul. Pada tahun 2019 BPTP Balitbangtan Sulawesi Barat menyediakan bibit kelapa dalam bermutu di tingkat lapangan sebanyak 3.000 bibit dalam polybag siap tanam. Hasil kegiatan yaitu Pembibitan kelapa dalam dilaksanakan di Kecamatan Mamuju, Kabupaten Mamuju, pada bulan Januari-Desember sebanyak 3.000 bibit Pelaksanaan kegiatan yang telah dilaksanan yaitu persiapan benih, persiapan lahan, penyemaian dan Pemelihraan, sertifikasi dan Penyaluran benih'Jumlah Bibit yang disemai sebanyak 3.000 dari target 3.000 batang. Jumlah bibit yang tumbuh baik dan lulus Sertfikasi sebayak 1.800 batang. bibit yang tidak dapat tumbuh dikarenaka serangan jamur dan mati pucuk akibat musim kemarau yang bekepanjangan.
\end{abstract}

Kata Kunci: diseminasi, teknologi, kelapa dalam, perbenihan

\section{Pendahuluan}

Kelapa adalah salah satu komoditi perkebunan yang sangat penting dalam perekonomian nasional yaitu sebagai penghasil minyak nabati dalam memenuhi kebutuhan masyarakat disamping sebagai komoditas ekspor. Hampir seluruh bagian tanaman dapat dimanfaatkan sehingga tanaman kelapa dijuluki sebagai pohon kehidupan (tree of life). Tanaman kelapa juga merupakan tanaman sosial karena lebih dari 95\% diusahakan oleh petani.

Sampai saat ini produktivitas Kelapa Dalam nasional masih rendah yaitu 1,1 ton kopra/ha/tahun. Di Sulawesi Barat, kelapa dalam termasuk salah satu komoditas perkebunan yang sangat prospektif dan potensial untuk pengembangan agroindustri, karena memiliki peranan yang sangat penting dalam menumbuhkan perekonomian daerah. Ini terlihat dari luas areal pertanaman kelapa dalam di Provinsi Sulawesi Barat yaitu 42.947 hektar dengan total produksi terus mengalami peningkat dari tahun $2017 \mathrm{ke}$ 2018 yakni dari 36.469 ton naik menjadi 36.644 ton (BPS Sulawesi Barat, 2019). Meskipun demikian produktivitasnya masih lebih rendah dari produktivitas nasional (sekitar 0,9 ton/ha). salah satu faktor yang menentukan tingginya produktivitas tanaman, termasuk kelapa adalah kualitas benih yang ditanam. Pemilihan benih kelapa dalam yang baik dan benar mutlak diperlukan untuk memperoleh benih unggul. Dengan menggunakan benih Kelapa Dalam unggul produktivitasnya dapat ditingkatkan menjadi > 1,5 ton kopra/ha/tahun.

Beberapa varietas Kelapa Dalam unggul yang sudah dilepas oleh Menteri Pertanian sebagai benih bina dan sudah banyak dikembangkan oleh masyarakat adalah Kelapa Dalam Mapanget (DMT), Kelapa Dalam Tenga (DTA), Kelapa Dalam Bali (DBI), Kelapa Dalam Palu (KDP),
Kelapa Dalam Sawarna (DSA), dan varietas Kelapa Dalam lainnya. Oleh karena itu untuk mendukung ketersedian benih sebar varietas unggul kelapa dalam di Sulawesi Barat, Balai Pengkajian Teknologi Pertanian Sulawesi Barat melalui Unit Pengelola Benih Sumber (UPBS) akan melakukan pendekatan sistem produksi benih dengan peningkatan kemampuan para penangkar (kelompok tani) penagkaran benih yang berbasis masyarakat, di mana masyarakat tani secara berkelompok (poktan) didorong memproduksi sendiri kebutuhan benihnya pada hamparan kelompoknya, sehingga akan lebih menghemat waktu dan biaya, dan untuk selanjutnya dapat menjadi unit produksi benih sumber yang berorientasi agribisnis.

\section{Kerangka Teori}

Pertanian merupakan sektor yang memegang peranan yang sangat strategis dalam pembangunan ekonomi nasional. Konstribusinya sangat nyata khususnya dalam menyokong penyediaan dan ketahanan pangan nasional, selain pengembangan komoditas ekspor dan substitusi impor serta komoditas penyedia bahan baku bio-energi.

Kelapa merupakan komoditas penting, karena memiliki berbagai keunggulan dalam meningkatkan nilai tambah. Hal ini tercermin dari kenyataan bahwa seluruh bagian tanaman kelapa dapat dimanfaatkan sebagai bahan pangan maupun bahan baku industri. Selain itu peranan kelapa bagi masyarakat Indonesia adalah: 1) sebagai sumber utama minyak nabati dalam negeri karena memiliki keunggulan tersendiri dibandingkan dengan kelapa sawit. Beberapa produknya seperti kelapa segar, santan, tepung kelapa kering ataupun kelapa parut kering (disiccated coconut) tidak dapat digantikan oleh produk komoditas lainnya. Dalam peranannya sebagai sumber minyak nabati, secara nasional 
rata-rata konsumsi masyarakat Indonesia 2,18 kg per kapita per tahun atau secara proporsional 22,4 \% dari total konsumsi minyak makan nasional (Kasryno, et al, 1998); 2) Peranannya sebagai komoditas ekspor dan sumber devisa negara, nilai ekspor produk kelapa pada tahun 2005 sebesar US \$ 579,3 juta, dengan nilai ekspor sebesar US\$ 937 milyar (Departemen Pertanian, 2005). Produk-produk kelapa yang di ekspor sebagian besar adalah produk tradisional atau produk primer yang menghadapi persaingan ketat di pasar Internasional dengan produk yang sama dari negara-negara produsen lainnya, maupun produk substitusi lainnya; 3) Peranannya sebagai sumber pendapatan, karena tanaman kelapa mempunyai kontribusi yang sangat besar, mengingat tanaman ini mempunyai kemampuan berproduksi sepanjang tahun secara terus menerus dan siap dijual untuk memenuhi kebutuhan keluarga petani. Kasryno et al. (1998) melaporkan bahwa penduduk yang menggantungkan hidupnya baik langsung maupun tidak langsung dari tanaman kelapa, tidak kurang 12,8 juta jiwa atau 14,5\% dari angkatan kerja (Kasryno et al., 1998); 4) Peranannya yang sangat strategis bagi pengembangan industri dalam negeri yang berbahan baku kelapa sejalan dengan usaha-usaha peningkatan pendapatan petani melalui program-program penganekaragaman produk kelapa dan aneka produk hasil samping yang bernilai ekonomi tinggi. Industri-industri tersebut antara lain: industri minyak goreng, industri pengolahan desiccated coconut, industri pengolahan santan kental, nata de coco, arang tempurung, sabut kelapa dan industri kerajinan; dan 5) Peranannya yang lain adalah sebagai penyedia lapangan kerja.

Luas areal pertanaman kelapa dalam di Provinsi Sulawesi Barat yaitu 47.504 hektar dengan total produksi terus mengalami peningkat dari tahun 2011 ke 2012 yakni dari 37.524 ton naik menjadi 43.645 ton (BPS Sulawesi Barat, 2013). Meskipun demikian produktivitasnya masih lebih rendah dari produktivitas nasional (sekitar 0,9 ton/ha). Agar produksi kelapa tidak menurun, maka pelaksanaan peremajaan dan rehabilitasi harus dilakukan terus-menerus karena tanaman menghasilkan (TM) akan menjadi tua, demikian pula dengan kerusakan akibat serangan hama dan penyakit dan bencana alam. Pada saat tanam, kepadatan tanaman kelapa rata-rata hanya 110 pohon/ha , tetapi ketika tanaman sudah dewasa dan tua mungkin hanya sekitar $80 \%$ dari populasi awal karena menurut Allolerung dan Mahmud (2003) kelapa tua perlu diremajakan karena tua dan rusak jika berada pada kisaran $20 \%$.

Untuk meningkatkan produktivitas yang saat ini tergolong rendah, maka dalam pelaksanaan peremajaan dan rehabilitasi diperlukan bibit yang bermutu yang berasal dari kebun induk, terutama kebun induk kelapa dalam komposit. Saat ini sumber benih kelapa yang digunakan belum berasal dari kebun induk yang dibangun khusus sebagai kebun induk yang benar, tetapi dipilih dari pertanaman yang ada di berbagai daerah yang disebut dengan blok penghasil tinggi (BPT). Kebiasaan petani dalam memenuhi kebutuhan bibit kelapa untuk tanaman baru yaitu (petani kelapa tidak pernah membuat tempat pembibitan), tetapi pembibitan secara alamiah, dengan cara mendapatkan/memilih buah yang mutunya baik dan berasal dari pohon induk yang menghasilkan buah yang banyak. Buah-buah tersebut kemudian dikumpulkan menjadi satu dan biarkan hingga tunas kelapa tumbuh, baru di tanam. Berdasarkan hasil penelitian, bahwa penggunaan kelapa dalam unggul komposit akan meningkatkan produksi kelapa dalam dari rata-rata 1,5 ton kopra ha-1 tahun-1 menjadi minimal 2,25 ton kopra ha-1 tahun-1 dengan pemeliharaan semi intensif. Produksi kelapa dalam unggul komposit dengan pemeliharaan intensif akan menyamai kelapa hibrida genja $x$ dalam yaitu berkisar 3-4 ton kopra ha-1 tahun-1. Produksi sangat stabil karena tetua kelapa dalam unggul komposit memiliki ragam genetik yang besar sehingga dapat beradaptasi pada lingkungan yang bervariasi.

Rendahnya penggunaan bibit berkualitas, kebijakan operasionalnya adalah dibangunnya industri pembibitan kelapa di sentra-sentra pembibitan produksi, dimana pemerintah menyiapkan fasilitas berupa: 1) menyiap-kan semua perangkat lunak untuk diperlukan seperti: Peraturan Menteri Pertanian No. 38/Permentan/OT.140/8/2006 tentang pema-sukan dan pengeluaran benih, Undang-Undang Budidaya No. 12, Undang-Undang Perkebunan No. 18, Perda dan perizinan dan lain-lain; dan 2) perangkat kerasnya berupa sumberdaya manusia, permodalan, keamanan dan lain-lain (Damanik, 2007). Selanjutnya untuk mendorong pemakaian bibit unggul adalah didirikannya industri bibit unggul, pengemasan dan pelebelan, harga bibit yang terjangkau dan mencegah beredarnya bibit palsu (Damanik, 2007). Sedangkan kebijakan untuk pengendali-an OPT (Organisme Pengganggu Tanaman) adalah penerapan paket pengendalian terpadu yang dapat menekan in-tensitas serangan. Integrasi tanaman kelapa dengan ternak merupakan bagian dari subsistem pro-duksi untuk mencegah resiko menurunnya produksi kelapa.

Pembibitan kelapa mempunyai peranan penting dalam keberhasilan pengembangan kelapa karena dapat menjadi indikator banyaknya produksi yang diperoleh atau dengan kata lain usaha perbaikan produktifitas tanaman kelapa harus dimulai sejak penyediaan bahan tanaman/bibit mengingat potensi produksi suatu tanaman tergantung pada bahan tanaman, cara penanganan dan perlakuan yang diberikan. Untuk mendapatkan bibit kelapa yang baik ada beberapa tahapan yang perlu dilakukan sehingga didapatkan pohon kelapa yang menghasilkan buah yang maksimal. Salah satu tahapan awal untuk mendapatkan pohon kelapa dengan produksi maksimal adalah teknik penyediaan bibit tanaman kelapa. Dengan teknik pembibitan dan seleksi bibit yang baik produksi buah yang diinginkan dapat dicapai. Tujuan pembibitan adalah untuk menghasilkan tanaman yang subur dan sehat dalam waktu yang relatif singkat. Keuntungan yang diperoleh dari bibit yang subur dan sehat antara lain : (a) menghasilkan tanaman yang seragam, (b) berbuah lebih awal dan (c) berproduksi tinggi (Suhardiyono, 1988).

Pertumbuhan tanaman yang baik akan mempercepat perubahan dari fase vegetatif ke generatif. Apabila pertumbuhan vegetatif terhambat maka perubahan kearah pertumbuhan generatif juga akan terhambat. Sebagai contoh, bibit yang perakarannya kurang baik akan mengurangi kemampuan tanaman untuk mengabsorpsi unsur hara dan air. Dengan demikian pertumbuhan tanaman akan terhambat dan sulit bersaing dengan gulma maupun tanaman lain. Menurut Allorerung et al. (2000), untuk mendapatkan bahan tanaman atau bibit kelapa yang baik perlu dilakukan tahapan pekerjaan mulai dari penyediaan bahan tanaman, pesemaian, pembibitan dan seleksi bibit. 
Untuk memastikan adopsi inovasi teknologi spesifik lokasi tersebut berjalan dengan baik, maka bebepara pertimbangan yang harus diperhatikan terutama sifat-sifat teknologi yang akan diintroduksi 1) Bermanfaat bagi petani secara nyata, 2) Lebih unggul dibandingkan dengan teknologi yang telah ada, 3) Bahan, sarana, alat mesin, modal dan tenaga untuk mengadopsi teknologi tersedia, 4) Memberikan nilai tambah dan keuntungan ekonomi, 5) Meningkatkan efisiensi dalam berproduksi, 6) Bersifat ramah lingkungan dan menjamin keberlanjutan usaha pertanian. Dari aspek petani, beberapa faktor yang biasanya menjadi pertimbangan sebelum mengadopsi teknologi yaitu 1) Ketersediaan pasar hasil panen dengan harga pasar yang layak serta keuntungan yang baik, 2) Kepastian diperolehnya hasil panen dengan resiko kegagalan yang minimal, 3) Penerapan teknologi tidak sulit bagi petani, 4) Petani mampu menyediakan modal untuk mengadopsi teknologi, dan 5) Memberikan nilai tambah dan keuntungan nyata bagi petani. Dalam proses adopsi inovasi teknologi kepada pengguna, akan mengalami proses dan tahapan yaitu kesadaran (awareness), tumbuhnya minat (interest), evaluasi (evaluation), mencoba (trial) dan adopsi (adoption) ( Rogers, 1983).

\section{Metode Penelitian}

\subsection{Tempat dan Waktu}

Kegiatan Inovasi perbenihan kelapa dalam dilaksanakan di Kecamatan Mamuju, Kabupaten Mamuju, Sulawesi Barat dari bulan Januari sampai Desember 2019.

\subsection{Alat dan Bahan}

Alat yang digunakan disesuaikan dengan peralatan yang dimiliki oleh petani di lokasi. Bahan habis pakai yang diperlukan, dihibahkan kepada petani yaitu benih kelapa dalam 3000 butir, p0lybag ukuran 30 x $40 \mathrm{~cm} 3000$ lembar, dan bahan pendukung lainnya.

\subsection{Tahapan Pelaksanaan Kegiatan}

\subsubsection{Koordinasi dan Sosialisasi Dalam \\ Perbenihan Kelapa}

Pada kegiatan ini, dilakukan sosialisasi teknologi perbenihan kelapa dalam terhadap petani pelaksana serta petugas lapangan, pemerintah daerah, dan pihak-pihak terkait lainnya untuk mendiskusikan tentang kegiatan yang dilakukan, transfer teknologi dan umpan balik sehingga dalam pelaksanaan kegiatan berjalan dengan lancar. Kegiatan tersebut petani dapat memperoleh informasi dan memahami kegiatan dilaksanakan dan diharapkan mampu menerapkannya. Sehubungan dengan itu, dukungan pengambil kebijakan sangat diperlukan agar penerapan teknologi tersebut oleh petani dapat terlaksana secara berkesinambungan.

\subsubsection{Pendampingan Pelaksanaan Perbenihan Kelapa Dalam}

Paket inovasi teknologi perbenihan kelapa dalam yang diterapkan pada petani/calon penangkar benih yang telah disepakati pada saat koordinasi dan sosialisasi dengan stakeholder terkait dalam pelaksanaannya, petani didampingi oleh teknisi dan peneliti BPTP Balitbangtan Sulawesi Barat.

\subsubsection{Proses Evaluasi dan Analisisnya}

Evaluasi kegiatan ini dilaksanakan secara partisipatif dengan melibatkan berbagai stake holder (Dinas Perkebunan, Penyuluh, dan petani). Kegiatan yang dievaluasi adalah alur kegiatan (proses) dan pelaksanaannya.

\section{Hasil dan Pembahasan}

\subsection{Koordinasi dengan Dinas Terkait}

Koordinasi dilakukan pada tingkat provinsi dan kabupaten. Koordinasi ditingkat provinsi dengan Dinas Pertanian Provinsi Sulawesi Barat bidang Produksi Tanaman Perkebunan. Sedangkan pada tingkat kabupaten , koordinasi dilakukan dengan Dinas Pertanian Kab.kabupaten Mamuju bidang Perkebunan. Koordinasi awal pelaksanaan kegiatan perbenihan kelapa dalam dilakukan untuk mendapatkan informasi lokasi tempat perbenihan. Selanjutnya koordinasi dilakukan di tingkat kabupaten dengan Dinas Pertanian Kabupaten Majene dalam rangka penyediaan benih sumber (benih kelapa dalam unggul lokal) sebagai kebun Induk Benih Kelapa.

\subsection{Penyiapan benih dan lahan persemaian}

Saat ini sumber benih kelapa yang digunakan belum berasal dari kebun induk yang dibangun khusus sebagai kebun induk yang benar, tetapi dipilih dari pertanaman yang ada di berbagai daerah yang disebut dengan blok penghasil tinggi (BPT). Kebiasaan petani dalam memenuhi kebutuhan bibit kelapa untuk tanaman baru yaitu (petani kelapa tidak pernah membuat tempat pembibitan), tetapi pembibitan secara alamiah, dengan cara mendapatkan/memilih buah yang mutunya baik dan berasal dari pohon induk yang menghasilkan buah yang banyak. Buah-buah tersebut kemudian dikumpulkan menjadi satu dan biarkan hingga tunas kelapa tumbuh, baru di tanam.

Usaha perbaikan produktifitas tanaman kelapa dalam harus dimulai sejak penyediaan bahan tanaman/bibit mengingat potensi produksi suatu tanaman tergantung pada bahan tanaman, cara penanganan dan perlakuan yang diberikan. Menurut Allorerung et al. (2000), untuk mendapatkan bahan tanaman atau bibit kelapa yang baik perlu dilakukan tahapan pekerjaan mulai dari penyediaan bahan tanaman, pesemaian, pembibitan dan seleksi bibit.

Benih kelapa dalam yang digunakan berasal dari pohon induk terpilih (nama petani pemilik pohon induk Acong, Desa Ulidan, Kecamatan Tammerodo Sendana, Kabupaten Majene). Kemudian benih diseleksi dengan criteria: bebas hama dan penyakit; ukuran buah normal, tidak terlalu besar atau kecil; warna buah kecoklatan dan licin sebagai tanda matang penuh; air buah kalau dikocok bunyinya nyaring.

Untuk memperoleh kecambah yang baik maka harus dipilih lokasi pembibitan yang memenuhi syarat antara lain : Tanah remah, subur dan dekat sumber air sehingga mudah untuk menyiram benih; lokasi datar dan terbuka agar mempermudah pesemaian dan pengawasan; pesemaian diusahakan dekat dengan jalan agar mempermudah transportasi. lokasi pesemaian terpilih, tanahnya dibersihkan dan diolah sedalam $30-40 \mathrm{~cm}$ secara manual dengan menggunakan cangkul. Bedengan pesemaian dibuat dengan ukuran lebar $1.5 \mathrm{~m}$ sedangkan panjang bedeng disesuaikan dengan kondisi dan keadaan setempat, maksimum $25 \mathrm{~m}$. 
Tinggi bedengan sekitar $25 \mathrm{~cm}$, dan jarak antar bedengan 60 $\mathrm{cm}$. Untuk keamanan pesemaian dibuat pagar untuk mencegah masuknya hewan.

Tabel. 1. Data Kebun Sumber Benih Kelapa Dalam Unggul Lokal di Kab. Majene

\begin{tabular}{cll}
\hline No & Uraian & Keterangan \\
\hline 1. & Luas Kebun Blok Penghasil & $4,57 \mathrm{Ha}$ \\
& Tinggi & 647 Pohon \\
2. & Jumlag Populasi & $196 \mathrm{Ha}$ \\
3. & Jumlah Pohon Induk Terpilih & 12.544 butir/tahun \\
4. & Taksasi Produksi benih & $8 \times 9 \mathrm{~m}$ \\
5. & Jarak tanam &
\end{tabular}

Sumber data; Dinas Kab. Majene (2018)

\subsection{Penyemaian dan pemeliharaan benih}

Benih kelapa yang telah disayat diletakkan (dideder) pada bedeng pesemaian dengan bagian yang disayat di bagian atas. Benih disusun secara zig zag, bagian yang disayat pada posisi satu arah. Bagian yang disayat diarahkan ke sebelah Timur (Gambar 1). Penyiraman dilakukan dengan mengunakan sprinkel secara otomatis dan dilakukan pada pagi dan sore hari. Pada saat musim hujan penyiraman dilakukan 1 kali pagi atau sore hari. Penyiangan dilakukan secara manual (pencabutan) dan Hama dan penyakit yang ada di lokasi dapat dikendalikan secara mekanis.

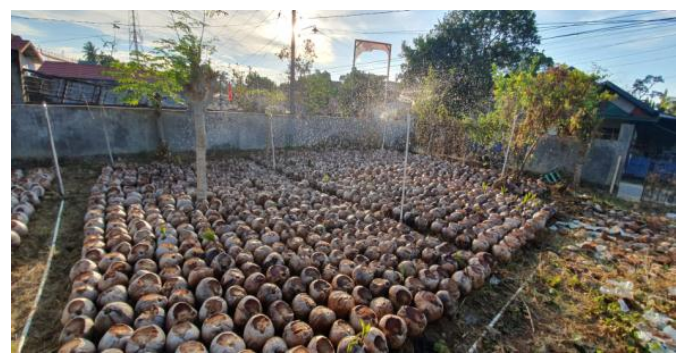

Gambar 1. Persemain Benih Kelapa di lahan.

\subsection{Pemindahan bibit pada Polybag}

Polibag yang digunakan terbuat dari polyethylene berwarna hitam dengan ukuran: panjang $40 \mathrm{~cm}$, tinggi 50 $\mathrm{cm}$ dan tebal $0.18 \mathrm{~mm}-0.20 \mathrm{~mm}$ yang sudah dilubangi. Polybag diisi dengan tanah gembur kemudian diatur jarak antar polibag agar tidak saling menghalangi penetrasi cahaya matahari.

Pemindahan kecambah ke polibag dilakukan dengan cara kecambah yang terseleksi dicabut dengan besi pengungkit atau cangkul melalui satu sisi benih kemudian tarik benih dengan seluruh akar utaman, kemudian akar akar utama dipotongg sehingga tersisa $5 \mathrm{~cm}$ dari kulit buah. Kecambah diletakkan dengan posisi tunas dibagian tengah polibag dan tegak, kemudian tanah disekitar benih dipadatkan dengan jari. Selanjutnya bibit dalam polibag disiram.

Pemeliharaan bibit seperti penyirama, penyiangan, dan pengendalian OPT dilakukan sesuai kebutuhan. Selain itu dilakukan juga penngamatn Tingg tanaman dan tingkat pertumbuhan tanaman Kelapa.

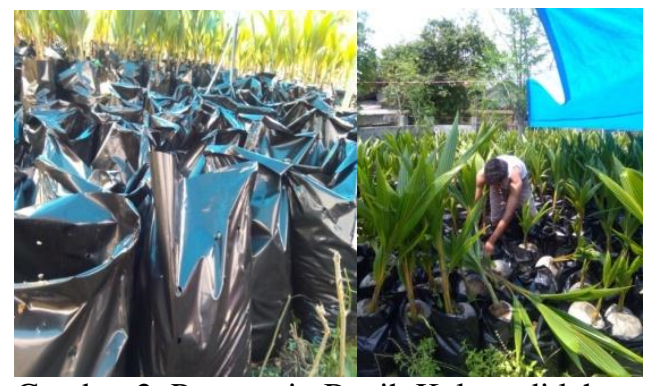

Gambar 2. Persemain Benih Kelapa di lahan.

Tabel. 2. Hasil pengamatan pertumbuhan Tanaman Kelapa Dalam Tahun tahun 2019

\begin{tabular}{|c|c|c|c|c|c|}
\hline \multirow{2}{*}{ No } & \multirow{2}{*}{\multicolumn{2}{|c|}{ Uraian }} & \multicolumn{3}{|c|}{ Umur Bibit } \\
\hline & & & 1 bulan & 3 bulan & 6 bulan \\
\hline 1. & Tinggi T & aman & 30 & 65 & 105 \\
\hline 2. & Jumlah I & & 3 & 4 & 6 \\
\hline 3 & $\begin{array}{l}\text { Jumlah } \\
\text { hidup }\end{array}$ & Yang & 2.500 & 2.000 & 1.868 \\
\hline \multirow[t]{2}{*}{4} & $\begin{array}{l}\text { Jumlah } \\
\text { Mati }\end{array}$ & Yang & 500 & 1.000 & 1.132 \\
\hline & Total & & 3.000 & 3.000 & 3.000 \\
\hline
\end{tabular}

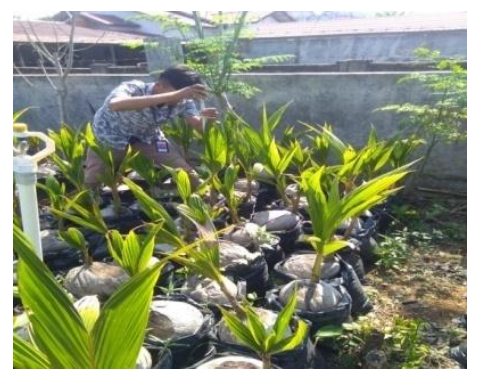

Gambar 3. Pengamatan dan pengukuran tinggi bibit kelapa.

\subsection{Sertifikasi Benih}

Sertifikasi benih dilakukan oleh instansi pemerintah yang mempunyai tugas pokok dan fungsi pengawasan mutu dan sertifikasi benih tanaman, antara lain Unit Pelaksana Teknis Pusat (UPTP) yaitu Balai Besar Pengawasan dan Pengujian Mutu Benih Tanaman Perkebunan (BBP2TP), Unit Pelaksana Teknis Daerah (UPTD) perbenihan tanaman perkebunan, Instansi Pengawasan dan Pengujian Mutu Benih (IP2MB) tanaman perkebuan dan bagi provinsi yang belum memiliki UPTD dilakukan oleh satuan tugas perbenihan yang dibentuk berdasarkan Surat Keputusan Kepala Dinas yang menangani perkebunan dengan didampingi oleh BBP2TP sesuai dengan wilayah kerjanya. Sertifikasi benih dilakukan dengan tujuan untuk menjaga kemurnian varietas melalui pemeriksaan lapangan dan pemeriksaan asal usul bibit, memelihara mutu benih melalui pemeriksaan kesehatan benih, memberikan jaminan kepada penggunan benih tentang kepastian mutu bibit dan varietas yang akan digunakan, memberikan legalitas kepada produsen benih bahwa benih yang dihasilkan terjamin kemurnian dan mutunya. Sertifikasi benih didasarkan atas Peraturan Menteri Pertanian Republik Indonesia No. 50/Permentan/KB.020/9/2015 Tentang Produksi, Sertifikasi, Peredaran dan Pengawasan Benih Tanaman Perkebunan, Tanggal 21 September 2015 (Menteri Pertanian, 2015). 
Hasil sertifikasi benih kakao oleh UPTD BP2MP Dinas Pertanian Prov. Sulbar berdasarkan Sertifikat Mutu Benih kakao nomor : 520/66/x/DISTAN/UPTD/2019, tanggal 16 Desember 2019, Kesimpulanya yaitu benih yang diperiksa sejumlah 2.500 batang dan mememuhi syarat sejumlah 1.800 batang, penyaluran benih kakao direncannakan untuk kabupaten mamuju dan untuk di lahan KP sertifikat berlaku sampai bulan Februari 2019.

\subsection{Kegiatan Monitoring dan Evaluasi}

Kegiatan Monitoring yang dilakukan di lokasi perbenihan Kelapa Dalam di Kab. Mamuju. Kegiatan yang dilakukan yaitu mengitung jumlah bibit yang tumbuh baik di dua lokasi tersebut. Jumlah Bibit yang disemai sebanyak 3.000 dari target 3.000 batang. Jumlah bibit yang tumbuh baik dan lulus Sertfikasi sebayak 1.800 batang. bibit yang tidak dapat tumbuh dikarenaka serangan jamur dan mati pucuk akibat musim kemarau yang bekepanjangan.

\section{Kesimpulan}

- Pembibitan kelapa dalam dilaksanakan di Kecamatan Mamuju, Kabupaten Mamuju, pada bulan JanuariDesember sebanyak 3.000 bibit

- Pelaksanaan kegiatan yang telah dilaksanan yaitu persiapan benih, persiapan lahan, penyemaian dan Pemelihraan, sertifikasi dan Penyaluran benih'

- Jumlah Bibit yang disemai sebanyak 3.000 dari target 3.000 batang. Jumlah bibit yang tumbuh baik dan lulus Sertfikasi sebayak 1.800 batang. bibit yang tidak dapat tumbuh dikarenaka serangan jamur dan mati pucuk akibat musim kemarau yang bekepanjangan

\section{Ucapan Terima Kasih}

Terima kasih kepada Dekan dan Ketua Program Studi Peternakan Fakultas Peternakan Universitas Hasanuddin atas dukungan dan bantuannya sehingga penelitian ini dapat diselesaikan yang merupakan penelitian tugas akhir (skripsi).

\section{Daftar Pustaka}

Allorerung D., Amrizal, Elsje Tenda, R.B. Maliangkay, M.L.A. Hosang, R.H. Akuba, N.L. Bari dan A. Lay. 2000. Petunjuk Teknis Budidaya Tanaman Kelapa (Cocos Nucifera)/. Balai Penelitian Tanaman Kelapa dan Palma Lain Manado pemberdayaan komoditas kelapa. Prosiding KNK V. Hal 70-85.

Badan Litbang Pertanian. 2005. Kumpulan Teknologi Unggulan Pendukung Prima Tani. Badan Litbang Pertanian. Jakarta. 75 p.

BPS Provinsi Sulawesi Barat. 2013. Sulawesi Barat Dalam Angka. Badan Pusat Statistik Propinsi Sulawesi Barat. Mamuju.

Damanik, S. 2007. Strategi Pengembangan Agribisnis Kelapa (Cocos nucifera) Untuk Meningkatkan Pendapatan Petani di Kabupaten Indragiri Hilir, Riau. Perspektif Review Penelitian Tanaman Industri. Badan Penelitian dan Pengembangan Pertanian. Pusat Penelitian dan Pengembagan Perkebunan.

Departemen Pertanian. 2005. Roadmap Komoditi Kelapa. Departemen Pertanian, Direktorat Jenderal Perkebunan Jakarta.
Kementan, 2014.Kebijakan Pembangunan Pertanian dan Pengembangan Kawasan 2015 - 2019. Materi Pramusrembang 2014.

Kasryno, F., Z. Mahmud \& P. Wahid. 1998. Sistem Usaha Pertanian Berbasis Kelapa. Prosiding Konperensi Nasional Kelapa IV, Bandar Lampung 21-23 April 1998.

Rogers, E. M. 1995. Diffusion of Innovation. New York, London, Toronto, Sydney, Tokyo, Singapore: The Free Press.

Suhardiyono. L. 1988. Tanaman Kelapa (Budidaya dan Pemanfaatannya) Penerbit Kanisius. Yogyakarta. 